\title{
Philately in molecular biology research of human gliomas in the era of omics
}

\author{
Juha E. Jääskeläinen • Emília Gaál-Paavola
}

Received: 10 February 2014 / Accepted: 10 February 2014 / Published online: 11 March 2014

(C) Springer-Verlag Wien 2014

WHO grade II-IV gliomas are profiled for a number of genes such as MGMT, TP53 and IDH1/2 or their proteins or other proteins such as KI-67 [1]. The combined profile of an individual glioma is of prognostic value and guides therapeutic choices in neuro-oncology group meetings - which is totally amazing as the present profiling only scratches the surface of the enormous bioinformatic data within the entire tissue volume of the profiled glioma. It is easier to believe that a gene here or a protein there does not mean much.

Philately of studying a single gene or protein expression in gliomas is mostly (1) outdated in the era of genomics and any omics and (2) fails to suggest new targets for synthetic antitumor drugs, which are thousands in store but will never be tested in gliomas with the present validation method of randomized multicenter trials. Or the reader should at least be provided with analyses and figures of the signaling pathways involved.

By DNA and RNA sequencing, we have just surveyed the ground floor of the department store of genomic information in each of our cells - and we know little of the information available in the upper floors (methylome, acetylome, histonome, etc.) up to the chromosomes ('chromosome'?). No one with a recent medical education can think that our body and brain are made from some 20,000 genes in our cells, making only some $1 \%$ of the whole genome. How is it possible that a fly with a pitiful 100.000 to 250.00 neurons can fly so precisely and quickly? This is because those neurons make a formidable aerobatic network of some $10^{7}$ synapses. Our own brain - the most complex machine in the known

J. E. Jääskeläinen $(\square)$

Neurosurgery, Kuopio University Hospital,

Kuopio, Finland

e-mail: juha.e.jaaskelainen@kuh.fi

E. Gaál-Paavola

Neurosurgery, Helsinki University Hospital, Helsinki, Finland universe - contains some $10^{15}$ synapses, an unimaginable network exceeding the combined capacity of all the computers in the world! This leads to three obvious questions:

1. Where and how are the blueprints of our entire human brain connectome stored within a single cell?

2. How is it possible that the cell - the only known selfreplicating machine in the universe - can exactly give its enormous genomic data to both daughter cells in cell division?

3. Where are the changing blueprints of glioblastoma tissue, one of the most thoroughly studied undesirable human tissues?

Many cancer centers are now creating bioinformatic logistics to try to utilize sequencing data in individual tumors in individual patients - personalized oncology [2]. This will require a brand new clinical speciality: clinical bioinformaticians. They will organize the logistics of sample transfer to a sequencing center close by or far off - and they will store, handle and analyze the huge date set per patient to be pondered, say, at neuro-oncology group meetings [3].

The senior author of this editoral has reviewed some 350 neuro-oncology manuscripts as an editorial board member of Acta Neurochirurgica. The titles reveal 21 manuscripts on a single gene or protein - but disastrously not the magic words such as sequencing, genomewide, exomic, transcriptomic, proteomic, metabolomic or bioinformatic. And PubMed revealed almost the same sad state in Acta Neurochirurgica.

Are our academic leaders and brilliant residents so fixed on various approaches or so disillusioned or so attracted by the forced 'free' time in the EU that they do not biobank tissues for bioinformatic analyses - I rather think that in the present climate they and their genomic collaborators have to publish in high-impact journals to maintain their funding. But at least reviews of bioinformatic analyses of various neurosurgical 
target tissues should be published in Acta for clinical neurosurgeons to grasp what may be waiting next door.

\section{References}

1. Weller M, Pfister SM, Wick W, Hegi ME, Reifenberger G, Stupp R (2013) Molecular neuro-oncology in clinical practice: a new horizon. Lancet Oncol 14(9):e370-e379. doi:10.1016/S1470-2045(13)70168-2

2. Roychowdhury S, Iyer MK, Robinson DR, Lonigro RJ, Wu YM, Cao X, Kalyana-Sundaram S, Sam L, Balbin OA, Quist MJ, Barrette T,
Everett J, Siddiqui J, Kunju LP, Navone N, Araujo JC, Troncoso P, Logothetis CJ, Innis JW, Smith DC, Lao CD, Kim SY, Roberts JS, Gruber SB, Pienta KJ, Talpaz M, Chinnaiyan AM (2011) Personalized oncology through integrative high-throughput sequencing: a pilot study. Sci Transl Med 3(111):111ra121. doi:10.1126/scitranslmed.3003161

3. Johnson BE, Mazor T, Hong C, Barnes M, Aihara K, McLean CY, Fouse SD, Yamamoto S, Ueda H, Tatsuno K, Asthana S, Jalbert LE, Nelson SJ, Bollen AW, Gustafson WC, Charron E, Weiss WA, Smirnov IV, Song JS, Olshen AB, Cha S, Zhao Y, Moore RA, Mungall AJ, Jones SJ, Hirst M, Marra MA, Saito N, Aburatani H, Mukasa A, Berger MS, Chang SM, Taylor BS, Costello JF (2014) Mutational analysis reveals the origin and therapy-driven evolution of recurrent glioma. Science 343(6167):189-193. doi:10.1126/science.1239947 